Original article

\title{
LUTEAL BLOOD FLOW AND GROWTH IN CORRELATION TO CIRCULATING ANGIOGENIC HORMONES AFTER SPONTANEOUS OVULATION IN MARES
}

\author{
E. A. ABDELNABY ${ }^{1} \&$ A. M. ABO EL-MAATY ${ }^{2}$ \\ ${ }^{1}$ Theriogenology Department, Faculty of Veterinary Medicine, Cairo \\ University, Egypt; ${ }^{2}$ Animal Reproduction and AI Department, \\ Veterinary Division, National Research Center, Dokki, Egypt
}

\begin{abstract}
Summary
Abdelnaby, E. A. \& A. M. Abo El-Maaty, 2017. Luteal blood flow and growth in correlation to circulating angiogenic hormones after spontaneous ovulation in mares. Bulg. J. Vet. Med., 20, No 2, 97-109.

For evaluating corpus luteum (CL) function, blood flow, circulating nitric oxide (NO), estradiol $\left(\mathrm{E}_{2}\right)$, progesterone, leptin and insulin like growth factor-I (IGF-1) concentrations were measured for 11 days that were equally divided into early and mid-luteal phases. Five mares underwent blood sampling and rectal Doppler ultrasound examination for 18 days for two estrous cycles. CL diameter, circumference, area and volume increased till day 11. Both blood flow blue area and power area increased from day 1 to 11 but colour blood flow red area declined till day 11 . NO concentration increased till day 5 then decreased till day 11. Leptin concentrations declined from day 1 to 11 . Power blood flow area and colour blood flow blue area exhibited a significant negative correlation with $\mathrm{E}_{2}$ $(\mathrm{r}=-0.79 ;-0.75)$, leptin $(\mathrm{r}=-0.73 ;-0.51)$, and IGF-1 $(\mathrm{r}=-0.56 ;-0.60)$, but had a positive one with progesterone $(\mathrm{r}=0.47 ; 0.52)$. Days after ovulation and luteal phase affected significantly luteal blood flow and hormone concentrations. The relatively high $\mathrm{E}_{2}$, leptin, IGF-1 and NO during growth compared to static phase indicated a role enhancing angiogenesis and early CL development.
\end{abstract}

Key words: Doppler, IGF-1, leptin, luteal vascular perfusion, mare, nitric oxide

\section{INTRODUCTION}

The corpus luteum (CL) is a small, transient endocrine gland formed following ovulation from the secretory cells of the ovarian follicles. The main secretory product of CL is progesterone, which regulates various reproductive functions (Khanghah \& kor, 2013). The extremely rapid CL tissue growth and angiogenesis rival those of even the fastest growing tumours (Reynolds et al., 2000). The luteal vascular tree is composed of arterioles and venules in the periphery of the CL; however, most of its area is composed of capillaries (Smith \& Meidan, 2014). During the CL life span, endocrine and vascular changes are dependant on the 
luteal angiogensis in the mare (FerreiraDias et al., 2006a,b). Doppler ultrasonography was used to determine normal and irregular alterations in the mare reproductive tract (Ignácio et al., 2011). In mares, the power Doppler display was used to evaluate CL (Bollwein et al., 2002a) and colour Doppler was also used to study luteal blood flow after induction of luteolysis (Ginther et al., 2007b). In horses, a close relationship between luteal blood flow and progesterone during the entire estrous cycle was found (Bollwein et al., 2002a; Ginther et al., 2007a). Ovarian artery of the mare was also used to evaluate CL which can be also done with the measurement of the CL area with coloured signals as an indicator of the extent of blood flow (Ignácio et al., 2011).

One of the growth factors that the CL produces and secretes is the insulinlike growth factor and one of the vasoactive factor that regulate luteal formation and development is nitric oxide (NO) (Miyamoto et al., 2010). In the ovary, insulin-like growth factor (IGF) is one of the numerous local factors that regulate the development of new capillaries from pre-existing ones (Berisha et al., 2016). Components of the IGF system were found within equine ovarian follicle (Donadeu \& Ginther, 2002) and played an important role in stimulating luteal angiogenesis (Chouhan et al., 2015). Insulinlike growth factor (IGF)-I had a stimulatory effect on leptin receptor expression of luteal cells (Gregoraszczuk et al., 2007).

NO synthesis has been localised to granulosa luteal cells identified by immunocytochemistry (Zackrisson et al., 1996). $\mathrm{NO}$ is a potential mediator of luteal development, maintenance, angiogenesis, and blood flow (Ferreira-Dias et al., 2011). The direct role of NO on CL blood flow as a local vasodilator depended on the CL stage (Acosta \& Miyamoto, 2004). In the mare, NO seems to be involved in CL development via stimulation of angiogenesis and progesterone secretion (Ferreira-Dias et al., 2011).

Leptin is secreted by adipocytes and might actively participate in the regulation of NO production (Tsuda \& Nishio, 2004). Leptin has been implicated in ovarian function, has immunoregulatory and angiogenic effects (Sierra-Honigmann et al., 1998). Physiological doses of leptin had induced endothelial nitric oxide synthase (eNOS) expression, which compensates, in part, for a lack of NO production by eNOS to maintain endothelium-dependent relaxation and leptin increased the plasma levels of nitrite, a marker for NO (Benkhoff et al., 2012). Leptin receptors are expressed not only in vascular but also in circulating cells (Benkhoff et al., 2012).

This study aimed to characterise the CL function and vascularity by evaluating CL dimensions (diameter, area, volume, and circumference), circulating leptin, NO, progesterone, estradiol, insulin like growth factor-I and vascularisation using colour and power Doppler ultrasound in spontaneously ovulated mares.

\section{MATERIALS AND METHODS}

\section{Animals}

Five non-lactating European $\times$ Egyptian crossbred broodmares (3-12 years old) of moderate body condition were subjected to ultrasonographic examination throughout two estrous cycles for each first 11 days after ovulation. Mares were given one week off rectal examinations between the two estrous cycles. Mares were granted from the Training Department (El-Basateen Horsley, Ministry of interior) and kept in an indoor paddock with partition individually with a pubertal colt 
at the end of the same stable to confirm estrus signs. Mares were kept under natural light and temperature and artificial light was used at night within the paddock. They were maintained on a commercial pelleted ration and hay with free access to water. Before directing this work, mares were examined 3 times at weekly interval by ultrasound to affirm ovarian cyclicity and ovulation. This study was conducted at the Department of Theriogenology, Faculty of Veterinary Medicine, Cairo University $\left(30.0276^{\circ} \mathrm{N}\right.$, $31.2101^{\circ} \mathrm{E}$ ) from June 15 to July 28 , 2014. The experiment was conducted in accordance with the Institutional Animal Care and Use Committee.

\section{Ultrasound scanning}

A pulsed-wave Doppler ultrasound scanner equipped with $12 \mathrm{MHz}$ linear-array transrectal transducer (Sonovet R3, Medison, Samsung, South Korea) was used for the examination of ovaries, by scanning follicles with a diameter $>1 \mathrm{~cm}$ in both ovaries for deciding the ovulatory one and the developing CL thereafter. Developing $\mathrm{CL}$ at the site of the ovulatory follicle was scanned in colour- and power Doppler modes. All scans were performed by the same operator during the study. All examinations were carried out at the same time (8:00-10:00 h a.m.) to avoid the high temperature and humidity. Days from 1 to 11 corresponded to days after ovulation when the CL was dominant as the disappearance of the large ovulatory follicle was considered the day of ovulation. After day 11 , the next ovulatory follicle attracted all the interest.

\section{Measurement of CL blood flow}

Whenever luteal tissue could be visualised, three different intersecting diameters of the CL were measured to estimate vo- lume $\left(4 / 3 \pi * D_{1} / 2 * D_{2} / 2 * D_{3} / 2\right)$ and area $\left(\pi * D_{1} / 2 * D_{2} / 2\right)$ using mathematical equations for ellipsoids assuming that the CL is a sphere with longer and thinner shape form ellipsoid (Bollwein et al., 2002a). Several scans of Doppler colour mode and the power mode of the luteal tissue were stored at the recording, with the maximum area, without flash artifacts, and with the maximum number of colour pixels in the CL. When the image on the screen was free of artifacts, the entire area, with a careful slow motion of the probe was recorded (Bollwein et al., 2002a; Ginther et al., 2007a). Either colour or power Doppler mode was activated; the blood flow area within the CL was quantified from the colour images. All scans were done at a pulse-repetition frequency and identical colour gain settings were used.

Areas of colour represented regions with a flow velocity more than $10 \mathrm{~mm} / \mathrm{s}$. The colour mode was used to determine the blood flow area within CL. The angle of insonation was not computed as a result of the small diameter of vessels, so care was taken to obtain maximum colour intensity.

\section{Image analysis}

Digital video recording was exported from the hard disk of the ultrasound machine to a PC. Three good pictures of CL (both in B-, colour- and Power-Mode) were chosen. Afterward, the chosen pictures were processed using image analysis software (Adobe PhotoShop CC software (19902013, Adobe Systems) for further detailed digital image analysis. The region of each $\mathrm{CL}$ was manually selected by the magnetic lasso tool in Photoshop and the following parameters were analysed: luteal blood flow (LBF) area away from the probe, which coloured blue (pixels), blood flow area toward the probe, which coloured red 
Luteal blood flow and growth in correlation to circulating angiogenic hormones after spontaneous...

(pixels) and single colour power blood flow area (pixels). The mean values of the three selected images were calculated and one mean value was used as referential. Percents of the coloured pixels were calculated by dividing coloured power area by the total CL area (in pixels) and was used as a quantitative index of the changes in blood flow within the luteal tissue.

\section{Blood sampling and hormonal assaying}

Daily blood samples were obtained from the jugular vein shortly after ultrasound examination using vacutainer tubes with anticoagulant ( $\mathrm{K}_{3}$ EDTA), then centrifuged at $2000 \mathrm{rpm}$ for $10 \mathrm{~min}$. Plasma was harvested and stored at $-18{ }^{\circ} \mathrm{C}$ until hormone assaying. All hormones were assayed using commercial ELISA (DRG, International, Inc., USA). Progesterone sensitivity was $0.045 \mathrm{ng} / \mathrm{mL}$. Intra- and inter-assay coefficients of variation of progesterone assay were 6.86 and $5.59 \%$. Estradiol sensitivity was $9.714 \mathrm{pg} / \mathrm{mL}$ but respective intra- and inter-assay coefficients of variation were 2.71 and $6.72 \%$. Leptin sandwich sensitivity was 1.0 $\mathrm{ng} / \mathrm{mL}$, with intra- and inter-assay coefficients of variation of 3.1 and $9.7 \%$. Insulin like growth factor-I (IGF-I) assay sensitivity was $1.29 \mathrm{ng} / \mathrm{mL}$ (intra- and interassay coefficients of variation of $6.62 \%$ and $7.79 \%$ ). Nitric oxide metabolites (NOMs) were measured by mixing equal volume of serum samples with freshly prepared Griess reagent, incubation for 10 min at room temperature; then absorbance was read at $540 \mathrm{~nm}$ against nitrite $\left(\mathrm{NO}_{2}\right)$ standards $(0-50 \mu \mathrm{M})$ using a microtiter plate reader as previously measured in our laboratory (Abdelnaby et al., 2016).

\section{Statistical analysis}

Data are presented as mean \pm SEM (standard error of mean) using SPSS software
(2007). Simple one-way ANOVA was used to study the influence of days after ovulation on CL area, volume, hormones and blood flow parameters (area of red colour toward the probe, blue colour away from the probe and power- flow Doppler mode). Data are presented in plots with error bars. The effect of luteal phase was also evaluated using independent sample $t$-test where early growth luteal phase (days 1 to 5) and mid-luteal static phase (days 6 to 11) after ovulation were compared. The Pearson correlation coefficient was also calculated.

\section{RESULTS}

Days after ovulation changed significantly $(\mathrm{P}=0.0001)$ both area $\left(\mathrm{cm}^{2}\right)$ and volume $\left(\mathrm{cm}^{3}\right)$ of the corpus luteum (CL). From day 1 after ovulation until day 11 , area $(9.30 \pm 0.46$ to $16.43 \pm 1.35)$ and volume $(14.47 \pm 1.11$ to $33.97 \pm 4.21)$ of $\mathrm{CL}$ increased significantly (Fig. 1). Values of CL circumference increased linearly from day 1 to 11 .

The area of colour signal away probe (blue/pixel) and power mode significantly $(\mathrm{P}<0.0001)$ increased during mid-luteal static phase but the area of the colour signal toward probe (red/pixel) and $\%$ of coloured pixels significantly $(\mathrm{P}<0.01)$ decreased (Table 1). Days after ovulation affected significantly $(\mathrm{P}<0.0001)$ vascular perfusion of the CL, at which blood flow area away from the probe (Fig. 2) increased significantly from day 1 (1621 \pm 39.8$)$ reaching a maximum on day $11(3355 \pm 189)$. The blood flow area toward the probe (red) decreased significantly $(\mathrm{P}=0.0001)$ from day $1 \quad(1417 \pm$ 57.8) until day $11(1021 \pm 76.1)$. Contrary, the power blood flow area/pixel significantly $(\mathrm{P}=0.001)$ increased from day 1 post ovulation $(2626 \pm 319.1)$ reaching a 


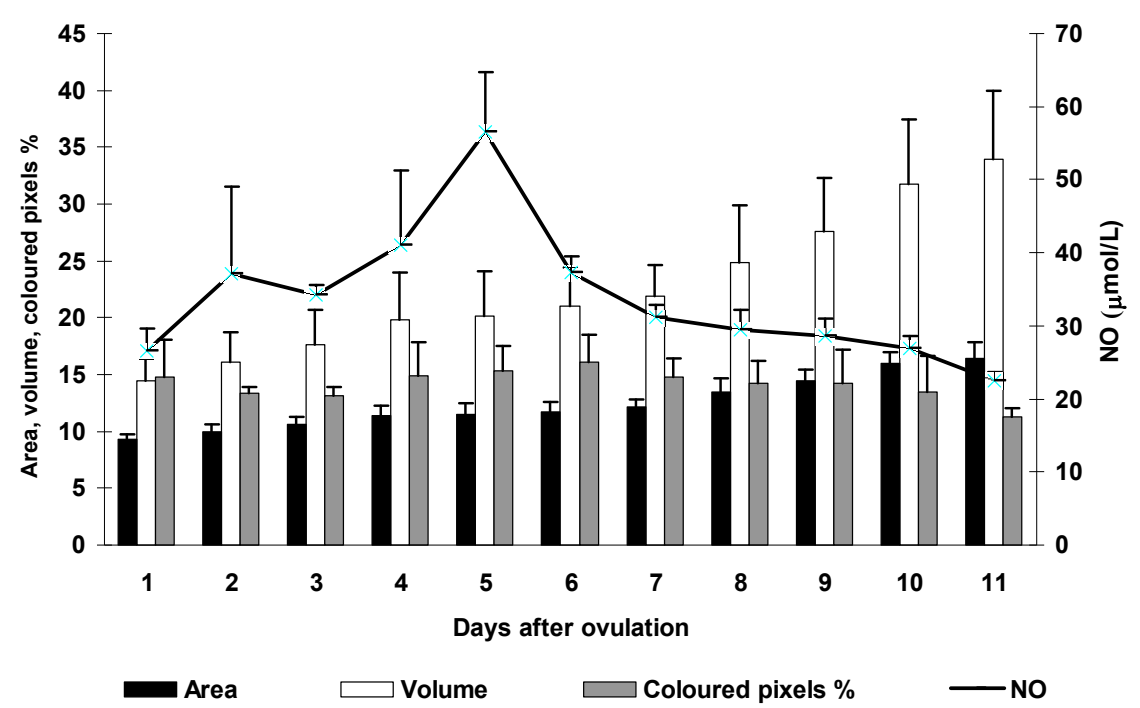

Fig. 1. Area $\left(\mathrm{cm}^{2}\right)$, volume $\left(\mathrm{cm}^{3}\right)$, colored pixels $(\%)$ and nitric oxide concentrations $(\mu \mathrm{mol} / \mathrm{L})$ during the first 11 days after ovulation. Data are presented as mean \pm SEM, $n=10$.

Table 1. Area of colour blood flow away from the probe, toward the probe, power blood flow and percent of coloured pixels for power blood flow mode of mare CL during the early and mid-luteal phase. Data are presented as mean $\pm \mathrm{SEM}, \mathrm{n}=10$

\begin{tabular}{lcccc}
\hline $\begin{array}{l}\text { Blood flow } \\
\text { area (px) }\end{array}$ & $\begin{array}{c}\text { Early (growth) phase): } \\
\text { days } 1 \text { to } 5\end{array}$ & $\begin{array}{c}\text { Mid (static) phase: } \\
\text { days } 6 \text { to } 11\end{array}$ & $\begin{array}{c}\text { Total: } \\
\text { days } 1 \text { to } 11\end{array}$ & P value \\
\hline $\begin{array}{l}\text { Away from the } \\
\text { probe (blue) }\end{array}$ & $1808.13 \pm 41.04$ & $2623.24 \pm 81.75$ & $2241.16 \pm 86.75$ & 0.0001 \\
$\begin{array}{l}\text { Toward the probe } \\
\text { (red) }\end{array}$ & $1354.47 \pm 24.31$ & $1141.65 \pm 24.37$ & $1241.41 \pm 25.53$ & 0.0001 \\
$\begin{array}{l}\text { Power-mode } \\
\text { Coloured pixels \% }\end{array}$ & $2678.20 \pm 71.99$ & $3626.06 \pm 102.99$ & $3181.75 \pm 105.94$ & 0.0001 \\
\hline
\end{tabular}

maximum on day $11(3981 \pm 216.5)$ with a slight decline on day $2(2491 \pm 31.9)$. The percent of coloured pixels of power blood flow mode was significantly affected by days after ovulation $(\mathrm{P}=0.03)$. It was significantly high on day 1 , but the lowest coloured pixels percent was observed on day 10 (Fig. 1).

$\mathrm{NO}(\mu \mathrm{mol} / \mathrm{L})$ concentration (Fig. 1) increased significantly $(\mathrm{P}=0.0001)$ from day $1(26.52 \pm 1.82)$ reaching a maximum level on day $5(56.53 \pm 4.69)$ then de- creased again to a minimum on day 11 (22.47 \pm 0.80$)$. NO decreased significantly $(\mathrm{P}=0.007)$ during the luteal static phase compared to the luteal growth phase (Table 2$)$. In contrast, leptin ( $\mathrm{ng} / \mathrm{mL})$ concentration significantly $(\mathrm{P}=0.003)$ decreased gradually from day $1(17.51 \pm 0.27)$ to reach a minimum level on day 10 (6.55 \pm 3.04$)$. Leptin $(\mathrm{P}=0.0001)$ concentrations were significantly lower during the luteal static phase compared to the luteal growth phase (Table 2). Progeste- 
Luteal blood flow and growth in correlation to circulating angiogenic hormones after spontaneous...

rone $\left(\mathrm{P}_{4} ; \mathrm{ng} / \mathrm{mL}\right)$ levels (Fig. 2) significantly increased $(\mathrm{P}=0.005)$ from day 1 post ovulation from $8.65 \pm 2.58$ reaching $15.70 \pm 0.56$ on day 10. Progesterone levels $(\mathrm{ng} / \mathrm{mL})$ were significantly $(\mathrm{P}=0.0001)$ high during static phase than during the luteal growth phase. Days after ovulation significantly affected IGF-1 $(\mathrm{P}=0.007)$ and estradiol $\left(\mathrm{E}_{2} ; \mathrm{P}=0.0001\right)$ levels.

Estradiol decreased significantly in a linear fashion from similar levels on days
1 and 2 post ovulation to significantly low concentrations on day 7 (Fig. 3). Then after a short increase on day 8 its levels decreased again to low values on day 10 . Concentrations of insulin like growth factor-1 (IGF-1) were significantly high from day 1 to day 6 then started to decline linearly from day 7 to day 11 (Fig. 3). IGF-1 $(P=0.0001)$ and estradiol $(P=0.0001)$ levels were significantly low during the

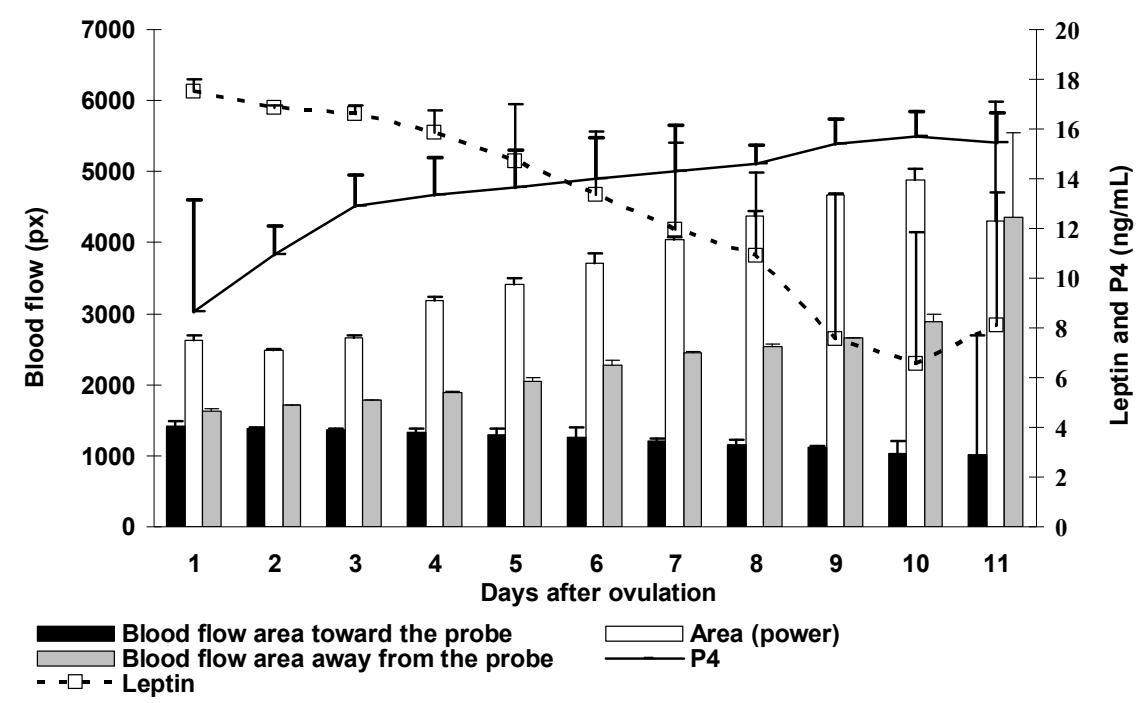

Fig. 2. Blood flow areas (colour-flow mode, power-flow mode) in pixels, progesterone $(\mathrm{ng} / \mathrm{mL})$ and leptin $(\mathrm{ng} / \mathrm{mL})$ concentrations during the first 11 days after ovulation.

Data are presented as mean \pm SEM, $n=10$.

Table 2. Circulating progesterone, leptin, nitric oxide metabolites, estradiol and insulin-like growth factor-1 (IGF-1) of mare during the early and mid-luteal phases. Data are presented as mean \pm SEM, $\mathrm{n}=10$

\begin{tabular}{lcccc}
\hline & $\begin{array}{c}\text { Early (growth) phase): } \\
\text { days } 1 \text { to } 5\end{array}$ & $\begin{array}{c}\text { Mid (static) phase: } \\
\text { days } 6 \text { to } 11\end{array}$ & $\begin{array}{c}\text { Total: } \\
\text { days } 1 \text { to } 11\end{array}$ & P value \\
\hline Progesterone $(\mathrm{ng} / \mathrm{mL})$ & $11.91 \pm 0.72$ & $14.88 \pm 0.30$ & $13.49 \pm 0.45$ & 0.0001 \\
Leptin $(\mathrm{ng} / \mathrm{mL})$ & $16.30 \pm 0.36$ & $9.83 \pm 1.08$ & $12.87 \pm 0.83$ & 0.0001 \\
Nitric oxide $(\mu \mathrm{mol} / \mathrm{L})$ & $39.08 \pm 3.18$ & $29.74 \pm 1.149$ & $34.12 \pm 1.79$ & 0.007 \\
Estradiol $(\mathrm{pg} / \mathrm{mL})$ & $190.11 \pm 4.72$ & $137.99 \pm 5.57$ & $163.21 \pm 5.97$ & 0.0001 \\
IGF-1 $(\mathrm{ng} / \mathrm{mL})$ & $327.41 \pm 13.90$ & $256.32 \pm 12.71$ & $290.72 \pm 11.29$ & 0.001 \\
\hline
\end{tabular}




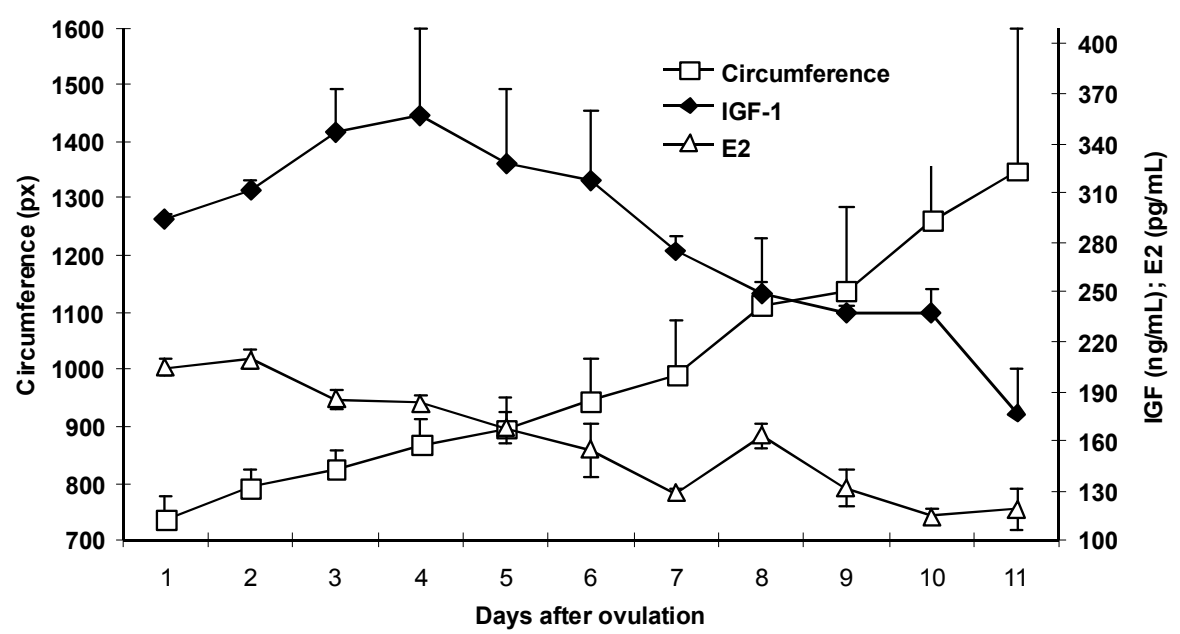

Fig. 3. Corpus luteum circumference (px), estradiol $(\mathrm{E} 2, \mathrm{pg} / \mathrm{mL})$ and insulin like growth factor-I (IGF-1, ng/mL) concentrations during the first 11 days after ovulation. Data are presented as mean $\pm \mathrm{SEM}, \mathrm{n}=10$.

mid-luteal static phase compared to the luteal growth phase (Table 2).

Correlations between CL dimensions, blood flow parameters and circulating hormones are presented in Table 3.

\section{DISCUSSION}

The day after ovulation significantly affected the area of CL in the present study and CL area of pony mares (Ginther et al., 2007a). After spontaneous ovulation, the progressive increase of CL area from day 1 to day 11 was also observed after induced ovulation from day 0 to day 8 (Romano et al., 2015). In contrast to the steady increase of luteal area and volume from day 1 till day 11 recorded during this study, CL area increased after ovulation and reached their maximum on day 2 (Bollwein et al., 2002a), day 4 (Ginther et al., 2007a) and mid-luteal phase (FerreiraDias et al., 2006b) followed by a slow decrease in cross-sectional area up to day 15 (Bollwein et al., 2002a) The positive correlation between CL area, volume and progesterone in mares in this study was also reported in pony mares (Ginther et al., 2007a).

Similarly, the day after ovulation had significantly affected the percentage of luteal area with colour signals of pony mares (Ginther et al., 2007a). In spontaneously ovulated mares of the current study, the increase of luteal vascularisation from day 1 to day 11 was also observed from day 0 to day 8 after induced ovulation (Romano et al., 2015). Based on histologic sections of all blood vessels in luteal tissue, the microvascular density increased during early and mid-luteal phase of equine corpora lutea (FerreiraDias et al., 2006b). Similar to the acute increase in luteal blood flow in mature CL periphery which correlated directly to progesterone, cyclic changes and individual differences in $\mathrm{CL}$ vascularisation were previously recorded in mares and the number of coloured pixels using power mode rose distinctly after ovulation until day 5 , then remained at a constant high level until day 7 (Bollwein et al., 2002a). The cyclic changes of luteal vascularisa- 
Luteal blood flow and growth in correlation to circulating angiogenic hormones after spontaneous...

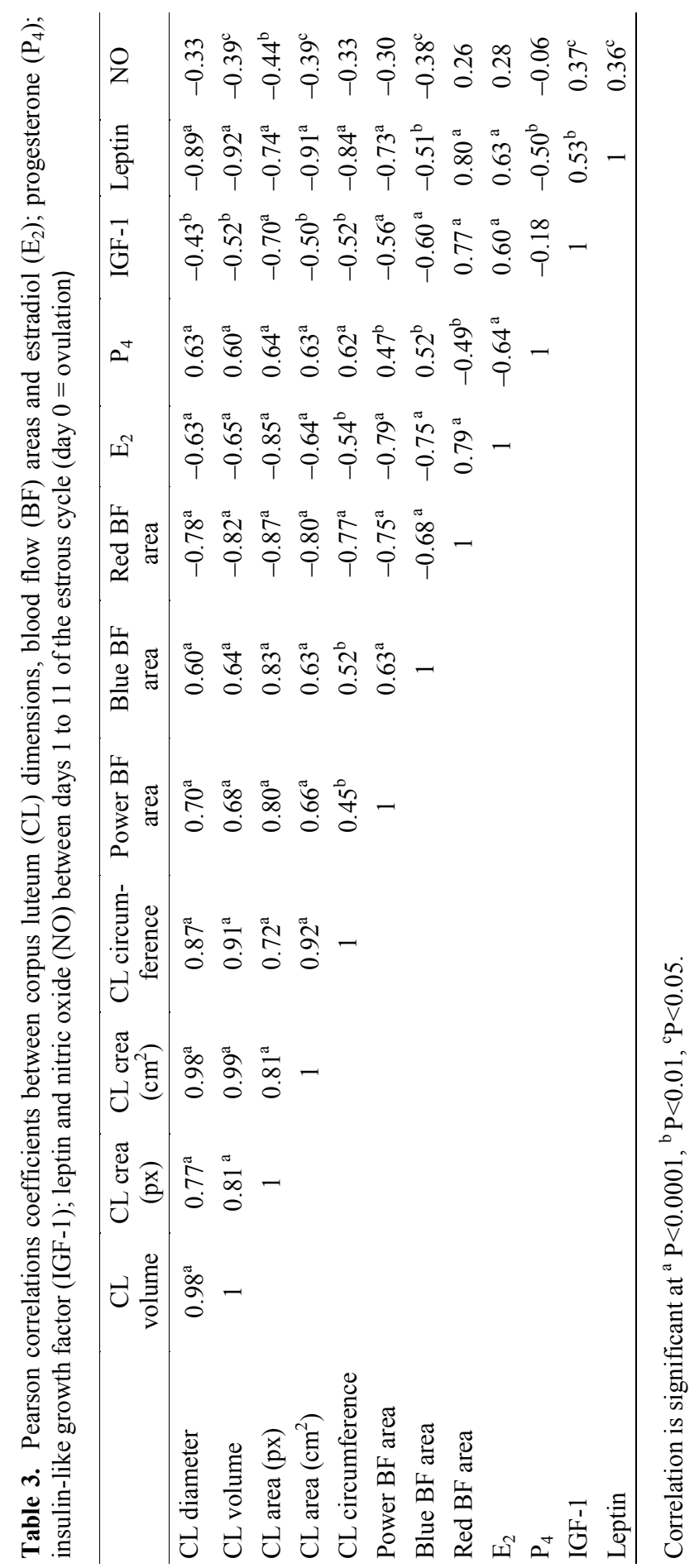


tion observed in mares of our study using colour mode were synchronous to the cyclic changes of uterine vascularisation of the same mares (Abdelnaby et al., 2015) and the cyclic changes of uterine artery measured by pulsatility index (PI) during untreated and estrogen-treated cycles (Bollwein et al., 2004). The increased resistance index (RI) indicated low blood flow and the reverse is true (Ferreria-Dias et al., 2011). Contrary to the changes of vascular perfusion determined using colour Doppler, the high PI values observed on day 1 , decreased until day 5 , and reincreased after that till day 15 as reported by Bollwein et al. (2004) whereas the luteal area of coloured pixels of mares of this study transiently declined during day 2 but continued increasing after that until day 11. Mean percentage of CL with colour-power Doppler signals for blood flow was high on days 1 and 6 but was maximum on day 10 in pony mares (Ginther et al., 2007a).

The steady increase of circulating $\mathrm{P}_{4}$ levels from day 1 to day 10 in our mares was similar to the progressive increase of plasma $\mathrm{P}_{4}$ presented after induced ovulation from day 0 to day 8 in mares (Romano et al. 2015), pony mares (Ginther et al., 2007a) and till mid-luteal phase (Ferreira-Dias et al., 2006b). $\mathrm{P}_{4}$ levels depended primarily on the luteal blood flow (Acosta et al., 2002). A close relationship between luteal blood flow and $\mathrm{P}_{4}$ has also been found in horses during the entire estrous cycle (Bollwein et al., 2002a; Ginther et al., 2007a). In mares, the close correlation between $\mathrm{CL}$ coloured pixels with $\mathrm{P}_{4}$ and area (Bollwein et al., 2002a) emphasises that a high luteal blood supply represents an important precondition for the secretion of $\mathrm{P}_{4}$. No indication was found that an acute increase or decrease in luteal blood flow occurred prior to the precipitous decrease in plasma $\mathrm{P}_{4}$ in pony mares (Ginther et al., 2007a). The absence of relationship between diameter of the CL and PI of the ipsilateral ovarian artery during diestrus (Bollwein et al., 2002b) was quite different from our results but the negative correlation between $\mathrm{PI}$ and $\mathrm{P}_{4}$ (Bollwein et al., 2002b) was similar to the positive correlation between $\mathrm{P}_{4}$ and power Doppler vascularisation area that could be referred to the close contact of majority of the steroidogenic cells of the CL with the capillaries (Reynolds et al., 1992). The circulation of the CL depended mainly on the day of the estrous cycle, so vascularisation precedes $\mathrm{P}_{4}$ synthesis (Acosta \& Miyamoto, 2004)

During early luteal development in mares of the present study, the increased circulating NO levels were accompanied by increased luteal blood flow and this could be attributed to NO from large arterioles surrounding CL (Miyamoto et al., 2005) and the role of NO and other factors in the CL blood flow increase (Skarzynski et al., 2008; Miyamoto \& Shirasuna, 2009). In vitro, NO donor increased the secretion of $\mathrm{P}_{4}$ and $\mathrm{PGF}_{2 \alpha}$ in early equine luteal tissue but not in midluteal tissue proving that NO may play a role in CL growth during early luteal development when vascular development is more intense (Ferreira-Dias et al., 2011) and indicated an angiogenic effect on CL. Locally eNOS protein was shown to be highly expressed in the mare early CL when NO had stimulated luteal tissue for angiogenic factors production (FerreiraDias et al., 2011). The decrease of circulating NO associated with the increase of $\mathrm{P}_{4}$ during luteal static phase in mares may be referred to increased levels of $\mathrm{NO}$ or NO-releasing agents that can inhibit steroidogenesis in granulose and luteal cells (Van Voorhis et al., 1994), since NO pro- 
duced locally inhibits NOS activity in ovarian tissue and has anti-steroidogenic effect, diminishing serum progesterone (Motta et al., 1997). The long-lasting effects of $\mathrm{P}_{4}$ and its precursor may inhibit angiogenic factor(s) production by equine mid-stage luteal cells, preparing for $\mathrm{CL}$ functional and structural regression (Ferreira-Dias et al., 2006a).

Leptin and insulin-like growth factor-I were considered angiogenic factors (Sarkanen et al., 2012). Treatment with leptin led to a concentration-dependent increase in cell number which was associated with an enhanced formation of capillary-like tubes in an in vitro angiogenesis assay and neovascularisation in an in vivo model of angiogenesis (Bouloumie et al., 1998). Ovaries are able to produce small amounts of leptin which modulate their function during different reproductive conditions (Fruhbeck, 2006). Both circulating and locally produced leptin may be involved in the luteal angiogenic process through regulation of potent angiogenic hormones and both leptin and its receptors had been identified in luteal tissue and were hypothesised to influence luteal vasculature through the regulation of $\mathrm{PGF}_{2 \alpha}$ (Wiles et al., 2014). The high serum leptin levels during early luteal growth compared to mid-luteal static phase of mares could be attributed to the decreased expression of leptin receptors during the mid-luteal stage compared to the early stage (Wiles et al., 2014). Also, the relaxing effect of leptin on blood vessels was partially mediated by the NO-dependent pathway and phenylephrine-contracted arterial rings were relaxed by leptin that mediated through endothelial NO production (Kimura et al., 2002).

In several species, IGF-1 enhances ovarian activity by stimulating granulosa and thecal cell proliferation and mitogene- sis (Deichsel et al., 2006). The spreading of capillaries appears to be induced by growth factors such as IGF-1 for supporting the synthesis of progesterone (Khanghah \& kor, 2013). The increased levels of IGF-1 during early luteal growth phase could be referred to their actions in enhancing ovarian activity through stimulating thecal cell proliferation and mitogenesis (Deichsel et al., 2006). Additionally, products of luteal origin such as $E_{2}$ and insulin like growth factor-1 (IGF-1) play a role in the regulation of these cells from apoptosis (Devoto et al., 2009). The positive correlation previously recorded between $E_{2}$ and leptin during foal heat in lactating Arabian mares (Abo El-Maaty \& Gabr, 2010) was also observed during the luteal phase of non-lactating mares but even higher and explain the synergistic actions of both hormones in regulating ovulation an corpus luteum development.

It could be concluded that power and colour blood flow vascularisation areas were greatly affected by the day after ovulation, luteal phase and circulating ovarian hormones, IGF-1, NO and leptin levels indicating their important role during early CL development.

\section{REFERENCES}

Abdelnaby, E. A., A. M. Abo El-Maaty, R. S A. Ragab \& A. A. Seida, 2016. Assessment of uterine vascular perfusion during the estrous cycle of mares in connection to circulating leptin, and nitric oxide concentrations. Journal of Equine Veterinary Science, 39, 25-32.

Abo El-Maaty, A. M. \& F. I. Gabr, 2010. Relation between leptin and estradiol level in Egyptian lactating Arab mares during foaling heat. Animal Reproduction Science, 117, 95-98.

Acosta, T. J. \& A. Miyamoto, 2004. Vascular control of ovarian function: Ovulation, CL 
formation and regression. Animal Reproduction Science, 82-83, 127-140.

Acosta, T. J., N. Yoshizawa, M. Ohtani \& A. Miyamoto, 2002. Local changes in blood flow within the early and midcycle CL after prostaglandin $\mathrm{F} 2$ alpha injection in the cow. Biology of Reproduction, 66, 651658.

Benkhoff, S., A. E. Loot, I. Pierson, A. Sturza, K. Kohlstedt, I. Fleming, H. Shimokawa, O. Grisk, R. P. Brandes \& K. Schröder, 2012. Leptin potentiates endotheliumdependent relaxation by inducing endothelial expression of neuronal NO synthase. Arteriosclerosis, Thrombosis, and Vascular Biology, 32, 1605-1612.

Berisha, B., D. Schams, D. Rodler \& M. W. Pfaffl, 2016. Angiogenesis in the ovary the most important regulatory event for follicle and CL development and function in cow - an overview. Anatomia, Histologia, Embryologia, 45, 124-130.

Bollwein, H., R. Mayer, F. Weber \& R. Stolla, 2002a. Luteal blood flow during the estrous cycle in mares. Theriogenology, 57, 2043-2051.

Bollwein, H., F. Weber, B. Kolberg \& R. Stolla, 2002b. Uterine and ovarian blood flow during the estrous cycle in mares. Theriogenology, 57, 2129-2138.

Bollwein, H., B. Kolberg \& R. Stolla, 2004. The effect of exogenous estradiol benzoate and altrenogest on uterine and ovarian blood flow during the estrous cycle in mares. Theriogenology, 61, 1137-1146.

Bouloumie, A., H.C.A. Drexler, M. Lafontan \& R. Busse, 1998. Leptin, the product of $\mathrm{Ob}$ gene, promotes angiogenesis. $\mathrm{Circu}$ lation Research, 83, 1059-1066.

Chouhan, V. S., S. S. Dangi, V. Babitha, M. R. Verma, S. Bag, G. Singh \& M. Sarkar, 2015. Stimulatory effect of luteinizing hormone, insulin-like growth factor-1, and epidermal growth factor on vascular endothelial growth factor production in cultured bubaline luteal cells. Theriogenology, 84, 1185-1196.
Deichsel, K., J. Aurich, N. Parvizi, R. M Bruckmaier \& C. Aurich, 2006. LH and IGF-1 release during oestrus and early luteal phase in lactating and non-lactating horse mares. Animal Reproduction Science, 91, 97-106.

Donadeu, F. X. \& O. J. Ginther, 2002. Changes in concentrations of follicularfluid factors during follicle selection in mares. Biology of Reproduction, 66, 1111-1118.

Devoto, L., A. Fuentes, P. Kohen, P. Céspedes, A. Palomino, R. Pommer \& J. F. Strauss, 2009. The human CL: Life cycle and function in natural cycles. Fertility and Sterility, 92, 1067-1079.

Ferreira-Dias, G., A. S. Costa, L. Mateus, A. Korzekwa, D. A. Redmer \& D. J. Skarzynski, 2006a. Proliferative processes within the equine CL may depend on paracrine progesterone actions. Journal of Physiology and Pharmacology, 57, 139-151.

Ferreira-Dias, G., P. P. Bravo, L. Mateus, D. A. Redmer \& J. A. Medeiros, 2006b. Microvascularization and angiogenic activity of equine corpora lutea throughout the estrous cycle. Domestic Animal Endocrinology, 30, 247-259.

Ferreira-Dias, G., A. S. Costa, L. Mateus, A. J. Korzekwa, A. Galvao, D. A. Redmer, K. Lukasik, A. Z. Szóstek, I. WoclawekPotocka \& D. J. Skarzynski, 2011. Nitric oxide stimulates progesterone and prostaglandin E2 secretion as well as angiogenic activity in the equine CL. Domestic Animal Endocrinology, 40, 1-9.

Frühbeck, G., 2006. Intracellular signalling pathways activated by leptin. Biochemical Journal, 393 (Pt 1), 7-20.

Ginther, O. J., E. L. Gastal, M. O. Gastal, M. D. Utta \& M. A. Beg, 2007a. Luteal blood flow and progesterone production in mares Animal Reproduction Science, 99, 213220.

Ginther, O. J., E. L. Gastal, M. O. Gastal \& M. A. Beg, 2007b. Effect of prostaglandin F2 $\alpha$ on ovarian adrenal and pituitary hormones and on luteal blood flow in mares. 
Luteal blood flow and growth in correlation to circulating angiogenic hormones after spontaneous...

Domestic Animal Endocrinology, 32, 315328.

Gregoraszczuk, E. Ł., A. Ptak, T. Wojciechowicz \& K. Nowak, 2007. Action of IGF-I on expression of the long form of the leptin receptor $\mathrm{ObRb}$ in the prepubertal period and throughout the estrous cycle in the mature pig ovary. Journal of Reproduction and Development, 53, 289-295.

Ignácio, F. S., J. C. Ferreira \& C. Meira, 2011. Uterine and luteal hemodynamic evaluation of the non pregnant mare. Acta Scientiae Veterinariae, 39, Suppl 1, s117-s121.

Khanghah, K. M. \& N. M. kor, 2013. A review of biology and function of corpus luteum (CL). Journal of Biology and Today's World, 2, 153-172.

Kimura, K., K. Tsuda, A. Baba, T. Kawabe, S. Bohoka, M. Ibata, C. Moriwaki, T. Hano \& I. Nishio, 2002. Involvement of nitric oxide in endothelium-dependent arterial relaxation by leptin. Biochemical Biophysical Research Communication, 273, 745749.

Miyamoto, A. \& K. Shirasuna, 2009. Luteolysis in the cow: A novel concept of vasoactive molecules. Animal Reproduction, 6, 47-59.

Miyamoto, A., K. Shirasuna, M. P. Wijayagunawardane, S. Watanabe, M. Hayashi, D. Yamamoto, M. Matsui \& T. J. Acosta, 2005. Blood flow: A key regulatory component of corpus luteum function in the cow. Domestic Animal Endocrinology, 29, 329-339.

Miyamoto, A., K. Shirasuna, T. Shimizu, H. Bollwein \& D. Schams, 2010. Regulation of corpus luteum development and maintenance: Specific roles of angiogenesis and action of prostaglandin F2alpha. Society of Reproduction and Fertility Supplement, 67, 289-304.

Motta, A. B., A. M. Franchi \& M. A. F. Gimeno, 1997. Role of nitric oxide mechanism of CL regression on uterine and ovarian prostaglandin synthesis during luteolysis in the rat. Prostaglandins, Leu- kotrienes, and Essential Fatty Acids, 56 , 265-269.

Reynolds, L. P., S. D. Killilea \& D. A. Redmer, 1992. Angiogenesis in the female reproductive system. Federation of American Societies for Experimental Biology, 6, 886-892.

Reynolds, L. P., A.T . Grazul-Bilska \& D. A. Redmer, 2000. Angiogenesis in the corpus luteum. Endocrine, 12, 1-9.

Romano, R. M., J. C. Ferreira, H. S. Canesin, Y. L. Boakari, F. S. Ignácio, L F. N. Filho, D. L. Thompson Jr. \& C. Meira, 2015. Characterization of luteal blood flow and secretion of progesterone in mares treated with human chorionic gonadotropin for ovulation induction or during early diestrus. Journal of Equine Veterinary Science, 35, 591-597.

Sarkanen, J. R., V. Kaila, B. Mannerström, S. Räty, H. Kuokkanen, S. Miettinen \& T. Ylikomi, 2012. Human adipose tissue extract induces angiogenesis and adipogenesis in vitro. Tissue Engineering Part A, 18, 17-25.

Sierra-Honigmann, M. R., A. K. Nath, C. Murakami, G. Garcia Gardena, A. Papapetropoulos, W. C. Sessa, L. A. Madge, J. S. Schechner, M. B. Schwabb, P. J. Polverini \& J. R. Flores-Riveros, 1998. Biological action of leptin as anangiogenic factor. Science, 281, 1683-1686.

Skarzynski, D. J., G. Ferreira-Dias \& K. Okuda, 2008. Regulation of luteal function and corpus luteum regression in cows: Hormonal control immune mechanisms and intercellular communication. Reproduction in Domestic Animals, 43, 57-65.

Smith, G. W. \& R. Meidan, 2014. Everchanging cell interactions during the life span of the corpus luteum: Relevance to luteal regression. Reproductive Biology 14, 75-82.

SPSS, 2007. Statistical Package for Social Sciences. SPSS Inc Chicago IL USA Copyright $($ ) for Windows version 160 SPSS.

Tsuda, K., \& I. Nishio, 2004. Role of leptin in regulating nitric oxide production and 
membrane microviscosity. Circulation, 109, e316.

Van Voorhis, B. J., M. S. Dunn, G. D. Snyder \& C. P. Weiner, 1994. Nitric oxide an autocrine regulator of human granulosaluteal cell steroidogenensis. Endocrinology, 135, 1799-1806.

Wiles, J. R., R. A. Katchko, E. A. Benavides, C. W. O'Gorman, J. M. Escudero, D. H. Keisler, R. L. Stanko \& M. R. Garcia, 2014. The effect of leptin on luteal angiogenic factors during the luteal phase of the estrous cycle in goats. Animal Reproduction Science, 148, 121-129.

Zackrisson, U., M. Mikuni, A. Wallin, D. Delbro, L. Hedin, \& M. Brännström, 1996. Cell-specific localization of nitric oxide synthases NOS in the rat ovary during follicular development ovulation and luteal formulation. Human Reproduction, $\mathbf{1 1}$ 2667-2673.

Paper received 15.01.2016; accepted for publication 08.04.2016

\section{Correspondence:}

Amal M. Abo El-Maaty

Animal Reproduction and AI Department, Veterinary Division,

National Research Centre,

Tahrir Street, Dokki, Giza, Egypt,

Postal code: 12622 ,

e-mail: amalaboelmaaty1@yahoo.com 